\title{
Calcium, Zinc and Phytate Interrelationships in Four Lesser-Known African Seeds Processed into Food Condiments
}

\author{
C.U. Igwe ${ }^{a^{*}}$, C.O. Ibegbulem ${ }^{b}$, L.A. Nwaogu ${ }^{c}$, C.O. Ujowundu ${ }^{d}$ and G.N. Okwu \\ Department of Biochemistry, Federal University of Technology, Owerri, Nigeria \\ ${ }^{a^{*} E-m a i l ~ a d d r e s s: ~ i g w e c h i d i @ y a h o o . c o m ~}$ \\ ${ }^{b}$ E-mail address: ibemog@yahoo.com \\ 'E-mail address: nwogulinus@yahoo.com \\ E-mail address: ujowundu@yahoo.com \\ eE-mail address: gnokwu@yahoo.com
}

\begin{abstract}
The calcium ( $\mathrm{Ca})$, zinc $(\mathrm{Zn})$ and phytate contents of raw, boiled, and boiled plus $72 \mathrm{~h}$ fermented samples of four lesserknown African seeds - Citrullus colocynthis, Cucumeropsis edulis, Ricinus communis and Prosopis africana - locally used for production of condiments in Nigeria were evaluated. Zinc bioavailability of the samples were also estimated using molar ratios per kg dry weight of [phytate]:[Zn], [Ca]:[phytate] and [phytate][Ca]:[Zn]. The levels of phytate, $\mathrm{Zn}$ and $\mathrm{Ca}$ of the raw seed samples varied from $150.01 \pm 11.00 \mathrm{mg} / 100 \mathrm{~g}$ (C. colocynthis) to $170.10 \pm 10.01 \mathrm{mg} / 100 \mathrm{~g}$ (C. edulis), $1.22 \pm$ $0.10 \mathrm{mg} / 100 \mathrm{~g}$ (C. colocynthis) to $4.79 \pm 0.14 \mathrm{mg} / 100 \mathrm{~g}$ (R. communis), and $28.33 \pm 2.58 \mathrm{mg} / 100 \mathrm{~g}$ (C. colocynthis) to 98.24 $\pm 15.19 \mathrm{mg} / 100 \mathrm{~g}$ (R. communis) respectively. The calculated values of [phytate]:[Zn], [Ca]:[phytate] and [phytate][Ca]:[Zn] molar ratios for the raw seeds indicated that the samples have low $\mathrm{Zn}$ bioavailability. However, a combined processing technique of boiling and fermentation together, unlike boiling alone, significantly $(p<0.05)$ improved these molar ratio markers, indicating high $\mathrm{Zn}$ bioavailability in condiments produced from these seeds. The implications of these findings with regards to management of $\mathrm{Zn}$ deficiency and the superabundance of these seeds are enormous.
\end{abstract}

\section{Indexing terms/Keywords}

Zinc bioavailability, Citrullus colocynthis, Cucumeropsis edulis, Ricinus communis, Prosopis africana.

\section{Academic Discipline And Sub-Disciplines}

Biochemistry

\section{SUBJECT CLASSIFICATION}

Nutritional Biochemistry

\section{TYPE (METHOD/APPROACH)}

Experimental study

\section{Council for Innovative Research}

Peer Review Research Publishing System

\section{Journal: Journal of Advances in Chemistry}

Vol 4, No.1

editor@cirworld.com

www.cirworld.com, member.cirworld.com 


\subsection{INTRODUCTION}

Condiments are substances which are used to give flavor to food or that is eaten with food. Local condiments are made traditionally from fermented seeds. Most of these are less known seeds, such as Citrullus colocynthis, Cucumeropsis edulis, Ricinus communis and Prosopis africana among others, used mostly in developing countries including Nigeria as low-cost protein and mineral sources. Their cooked forms are eaten as meals and are commonly used in fermented form as condiment to enhance the flavor of some foods [1]. Local flavoring condiments are prepared by traditional methods involving boiling and uncontrolled solid state fermentation resulting in extensive hydrolysis of protein and carbohydrate components [2] to yield products locally referred to as 'ogiri' by Southeastern, 'iru' by Southwestern and 'dawadawa' by Northern Nigerians. These processing techniques have also been reported to variously affect the mineral compositions of food. While Ogbonna et al.[3] observed an increase in calcium, phosphorus and potassium contents of fermented African yam bean, Achinewhu [4] reported decrease in iron and zinc contents of fermented fluted pumpkin. The presence and bioavailability of some of these minerals are further affected by the presence in the seeds of certain anti-nutrients such as phytate.

Phytate is a hexaphosphate ester of inositol that is widespread in plant seeds and grains, roots and tubers, nucleated erythrocytes of birds and turtles, and organic soils [5]. The amount of phytate present in a food depends mainly on the different processing methods used ${ }^{6}$. Phytate can decrease the absorption of minerals such as zinc, calcium, iron and manganese, and thus at high intake levels might lead to mineral deficiency [7]. Zinc deficiency is among the common nutritional problems in the world today [8]. Phytate may reduce the bioavailability of dietary zinc by forming insoluble mineral chelates at physiological $\mathrm{pH}$ [9]. The formation of the chelates is dependent on the relative concentrations of both zinc and phytate [10]. The rate of formation and stability of these chelates may also depend on levels of dietary calcium present. This is because, a kinetic synergism exists between the calcium and zinc ions resulting in a Ca:Zn:phytate complex which is less soluble than phytate complex formed by either ion alone [5].

In foods, [phytate]:[Zn] and [phytate][Ca]:[Zn] molar ratios are considered better indicators for determining potency of zinc bioavailability than total dietary phytate levels alone [5,11]. Staple diets having high molar ratios of [phytate]:[Zn] and/or [phytate][Ca]:[Zn] have been suggested to be associated with increased relative risk of zinc deficiency. Ellis et al. [12] had previously suggested that the critical values of [phytate]:[Zn] and [phytate][Ca]:[Zn] are greater than 10 and greater than 200 , respectively. Similarly, according to WHO [13] cut-offs in a special food, [phytate]:[Zn] molar ratios of $\geq 15,5-15$ and $<5$ are equal to zinc bioavailability as low (10-15\%), moderate (30-35\%) and high (50-55\%), respectively. These factors are of immense importance in the evaluation of the recommended dietary allowance (RDA) of zinc and may be necessary in predicting relativity of zinc deficiency in a population based on common staple foods consumed in the locality. Notwithstanding the importance of [phytate]:[Zn] and [phytate][Ca]:[Zn] interactions for human zinc status, data on phytate content and zinc bioavailability of foods are scarce. Thus, this study is aimed at determination of the calcium, phytate and zinc contents of raw, boiled and fermented forms of four lesser-known African seeds, namely Citrullus colocynthis, Cucumeropsis edulis, Ricinus communis and Prosopis africana. The [phytate]:[Zn], [Ca]:[phytate] and [phytate][Ca]:[Zn] molar ratios of the raw seeds and their processed products were also calculated.

\subsection{MATERIALS AND METHODS}

\subsection{Collection and Processing of Seed Samples}

Apparently healthy seed samples of Prosopis Africana and Ricinus communis were purchased at Markurdi Main Market, Markurdi, Benue State, while Cucumeropsis edulis and Citrullus colocynthis were bought from Ekeonuwa Market, Owerri, Imo State, both in Nigeria. The seeds were identified by a taxonomist at the Department of Forestry and Wildlife Technology, Federal University of Technology, Owerri, Nigeria.

Each of the seed samples was divided into three portions and processed as follows:

\subsubsection{Raw Seed Samples}

One portion of each of seed sample was dried to a constant weight in an oven (Gallenkamp model III-100) at $60^{\circ} \mathrm{C}$, deshelled, ground into fine powder using a manual grinder, sieved through a No. 20 mesh sieve and stored in a dry airtight labeled glass container in a refrigerator prior to analysis.

\subsubsection{Boiled Seed Samples}

The second portion of each seed sample was boiled for $12 \mathrm{~h}$, de-shelled and ground into a paste. The paste was dried in the oven at $60^{\circ} \mathrm{C}$ to a constant weight and stored in another set of labeled glass container in a refrigerator until analysis.

\subsubsection{Fermented Seed Samples}

The third portion of each seed sample was boiled for $12 \mathrm{~h}$, de-shelled and ground into a paste. Each paste was wrapped in a muslin cloth and allowed to ferment at room temperature $\left(\approx 28^{\circ} \mathrm{C}\right)$ for $72 \mathrm{~h}$. At the end of the fermentation period, each sample was dried in the oven at $60^{\circ} \mathrm{C}$ to a constant weight and stored in an appropriately labeled glass container in a refrigerator until analysis. 


\subsection{Determination of Phytate Content}

Phytate content of samples was determined using colorimetric (UV-visible spectrophotometer, Genway Model 6000, England) method [14]. Standard phytic acid and blank solutions were also prepared and ran along with the test samples as earlier described[14].

\subsection{Determination of Zinc and Calcium Contents}

Two grams of each sample were wet-digested with heat and concentrated $\mathrm{HNO}_{3} / \mathrm{H}_{2} \mathrm{SO}_{4}(7.5 \mathrm{ml}$ and $5 \mathrm{ml}$ respectively) solution. After the material begins to char, digestion was continued with only $\mathrm{HNO}_{3}$ until a light yellow liquid was obtained. The $\mathrm{Zn}$ and $\mathrm{Ca}$ concentrations were determined with the aid of an atomic absorption spectrophotometer (Analyst 700 series, Perkin Elmer, Germany) according to the manufacturer's instructions.

\subsection{Calculation of the mole ratios}

The [phytate]:[Zn], [Ca]:[phytate] and [Ca][phytate]:[Zn] mole ratios were calculated as previously described [15, 16].

$\begin{array}{lll}{[\text { Phytate }]:[\mathrm{Zn}]} & = & \frac{\text { Phytate }(\mathrm{mg} / 100 \mathrm{~g}) / 660}{\text { Zinc }(\mathrm{mg} / 100 \mathrm{~g}) / 65.38} \\ {[\mathrm{Ca}]:[\text { Phytate }]} & = & \frac{\text { Calcium }(\mathrm{mg} / 100 \mathrm{~g}) / 40.08}{\text { Phytate }(\mathrm{mg} / 100 \mathrm{~g}) / 660} \\ {[\text { Ca][phytate]:[Zn] }=} & \frac{[\text { Phytate }(\mathrm{mg} / 100 \mathrm{~g}) / 660] \times[\text { Calcium }(\mathrm{mg} / 100 \mathrm{~g}) / 40.08]}{[\text { Zinc }(\mathrm{mg} / 100 \mathrm{~g}) / 65.38]}\end{array}$

\subsection{Statistical Analysis}

All determinations were carried out in duplicates and expressed as mean \pm standard deviations. One-way analysis of variance (ANOVA) and posthoc Tukey test were used to analyze data generated with the aid of GraphPad Prism version 5.3 and differences at $p \leq 0.05$ were considered significant.

\subsection{RESULTS}

Table 1 presents the concentrations of phytate, $\mathrm{Zn}$ and $\mathrm{Ca}$, as well as the levels of [phytate]:[Zn], [Ca]:[phytate] and [Ca][phytate]:[Zn] molar ratios of the raw seed samples. It shows that phytate content ranged from $150.01 \pm 11.00$ $\mathrm{mg} / 100 \mathrm{~g}$ in C. colocynthis to $170.10 \pm 10.01 \mathrm{mg} / 100 \mathrm{~g}$ in $C$. edulis. The $\mathrm{Zn}$ and Ca contents were highest in $R$. communis $(4.79 \pm 0.14$ and $98.24 \pm 15.19 \mathrm{mg} / 100 \mathrm{~g}$ respectively) and lowest in C. colocynthis $(1.22 \pm 0.10$ and $28.33 \pm 2.58 \mathrm{mg} / 100 \mathrm{~g}$ respectively). The [phytate]:[Zn] molar ratio of $C$. cucumeropsis and $R$. communis were significantly $(p<0.05)$ lower at 5.05 \pm 1.77 and $3.35 \pm 0.40$ than those of $C$. colocynthis and $P$. africana at $11.81 \pm 0.18$ and $7.22 \pm 1.48$ respectively. On the other hand, the[Ca]:[phytate] molar ratios of the raw seeds were significantly $(\mathrm{p}<0.05)$ higher in $R$. communis $(10.11 \pm$ $2.44)$ and $C$. edulis $(8.02 \pm 0.90)$ than $C$. colocynthis $(3.22 \pm 0.49)$ and $P$. africana $(3.66 \pm 0.98)$. There was no significant ( $p>0.05$ ) difference in the [Ca][phytate]:[Zn] molar ratios of all the raw seeds, which ranged from $0.64 \pm 0.03$ to $0.99 \pm 0.18$ $\mathrm{mol} / \mathrm{kg}$ in $P$. africana and $C$. edulis respectively.

Table 1: Concentrations of phytate, $\mathrm{Zn}, \mathrm{Ca}$ and calculated [phytate]/[Zn], [Ca]/[phytate] and [Ca][phytate]/[Zn] molar ratios of the raw seeds analyzed.

\begin{tabular}{lcccccc}
\hline $\begin{array}{c}\text { Sample } \\
\text { (dry weight) }\end{array}$ & $\begin{array}{c}\text { Phytate } \\
(\mathbf{m g} / \mathbf{1 0 0 g})\end{array}$ & $\begin{array}{c}\text { Zn } \\
(\mathbf{m g} / \mathbf{1 0 0 g})\end{array}$ & $\begin{array}{c}\text { Ca } \\
(\mathbf{m g} / \mathbf{1 0 0 g})\end{array}$ & $\begin{array}{c}\text { [Phytate] } \\
{[\mathbf{Z n}]}\end{array}$ & $\begin{array}{c}\text { [Ca] } \\
{[\text { Phytate] }}\end{array}$ & $\begin{array}{c}\text { [Ca][Phytate] } \\
{[\mathbf{Z n}]}\end{array}$ \\
\hline Citrullus colocynthis & $150.01 \pm 11.00^{\mathrm{a}}$ & $1.22 \pm 0.10^{\mathrm{a}}$ & $28.33 \pm 2.58^{\mathrm{a}}$ & $11.81 \pm 0.18^{\mathrm{a}}$ & $3.22 \pm 0.49^{\mathrm{a}}$ & $0.83 \pm 0.09^{\mathrm{a}}$ \\
Cucumeropsis edulis & $170.10 \pm 10.01^{\mathrm{a}}$ & $3.48 \pm 1.40^{\mathrm{ab}}$ & $80.57 \pm 13.67^{\mathrm{b}}$ & $5.05 \pm 1.77^{\mathrm{b}}$ & $8.02 \pm 0.90^{\mathrm{ab}}$ & $0.99 \pm 0.18^{\mathrm{a}}$ \\
Ricinus communis & $160.03 \pm 10.00^{\mathrm{a}}$ & $4.79 \pm 0.14^{\mathrm{b}}$ & $98.24 \pm 15.19^{\mathrm{b}}$ & $3.35 \pm 0.40^{\mathrm{b}}$ & $10.11 \pm 2.44^{\mathrm{b}}$ & $0.81 \pm 0.03^{\mathrm{a}}$ \\
Prosopis africana & $170.00 \pm 12.01^{\mathrm{a}}$ & $2.29 \pm 0.21^{\mathrm{ab}}$ & $36.20 \pm 5.59^{\mathrm{a}}$ & $7.22 \pm 1.48^{\mathrm{ab}}$ & $3.66 \pm 0.98^{\mathrm{a}}$ & $0.64 \pm 0.03^{\mathrm{a}}$ \\
\hline
\end{tabular}

Values (mean \pm standard deviation) with different superscripts per column are statistically significant $(\mathrm{p}<0.05)$.

As shown in Table 2, the phytate content of the boiled seeds ranged from $110.05 \pm 12.02$ in C. colocynthis to $131.01 \pm$ $12.32 \mathrm{mg} / 100 \mathrm{~g}$ in $P$. africana. Zn content of the boiled seed samples was significantly $(\mathrm{p}<0.05)$ highest in $R$. communis, while Ca content was also significantly $(\mathrm{p}<0.05)$ higher in $C$. edulis and $R$. communis than the other seed samples. The [phytate]:[Zn] molar ratio was significantly $(p<0.05)$ reduced, while [Ca]:[phytate] molar ratio was significantly $(p<0.05)$ increased in boiled $C$. edulis and $R$. communis in comparison with their respective values in $C$. colocynthis and $P$. africana. As in the raw seeds, there were no significant $(p>0.05)$ differences in the [Ca][phytate]:[Zn] molar ratios of all the boiled seed samples. 
Table 2: Concentrations of phytate, $\mathrm{Zn}, \mathrm{Ca}$ and calculated [phytate]/[Zn], [Ca]/[phytate] and [Ca][phytate]/[Zn] molar ratios of the boiled seeds analyzed.

\begin{tabular}{lcccccc}
\hline $\begin{array}{c}\text { Sample } \\
\text { (dry weight) }\end{array}$ & $\begin{array}{c}\text { Phytate } \\
(\mathbf{m g} / \mathbf{1 0 0 g})\end{array}$ & $\begin{array}{c}\text { Zn } \\
(\mathbf{m g} / \mathbf{1 0 0 g})\end{array}$ & $\begin{array}{c}\text { Ca } \\
(\mathbf{m g} / \mathbf{1 0 0 g})\end{array}$ & $\begin{array}{c}\text { [Phytate] } \\
{[\mathbf{Z n}]}\end{array}$ & $\begin{array}{c}\text { [Ca] } \\
\text { [Phytate] }\end{array}$ & $\begin{array}{c}\text { [Ca][Phytate] } \\
{[\mathbf{Z n}]} \\
(\mathbf{m o l} / \mathbf{k g})\end{array}$ \\
\hline Citrullus colocynthis & $110.05 \pm 12.02^{\mathrm{a}}$ & $0.97 \pm 0.16^{\mathrm{a}}$ & $20.20 \pm 2.40^{\mathrm{a}}$ & $10.92 \pm 0.88^{\mathrm{a}}$ & $3.16 \pm 0.12^{\mathrm{a}}$ & $0.55 \pm 0.03^{\mathrm{a}}$ \\
Cucumeropsis edulis & $130.71 \pm 14.10^{\mathrm{a}}$ & $3.20 \pm 0.21^{\mathrm{ab}}$ & $72.35 \pm 5.44^{\mathrm{b}}$ & $3.85 \pm 0.91^{\mathrm{b}}$ & $9.83 \pm 2.22^{\mathrm{b}}$ & $0.70 \pm 0.22^{\mathrm{a}}$ \\
Ricinus communis & $130.63 \pm 10.41^{\mathrm{a}}$ & $6.09 \pm 1.41^{\mathrm{b}}$ & $53.85 \pm 1.91^{\mathrm{c}}$ & $2.13 \pm 0.26^{\mathrm{b}}$ & $6.93 \pm 0.50^{\mathrm{ab}}$ & $0.29 \pm 0.03^{\mathrm{a}}$ \\
Prosopis africana & $131.01 \pm 12.32^{\mathrm{a}}$ & $2.08 \pm 0.11^{\mathrm{a}}$ & $32.10 \pm 2.69^{\mathrm{a}}$ & $6.13 \pm 0.35^{\mathrm{c}}$ & $4.11 \pm 0.08^{\mathrm{a}}$ & $0.49 \pm 0.07^{\mathrm{a}}$
\end{tabular}

Values (mean \pm standard deviation) with different superscripts per column are statistically significant $(p<0.05)$.

Table 3 shows that the phytate and $\mathrm{Zn}$ contents of all the boiled and later fermented seeds were not significantly $(p<0.05)$ different. The $\mathrm{Ca}$ content of the fermented seeds ranged from $60.61 \pm 3.61 \mathrm{mg} / 100 \mathrm{~g}$ in $P$. africana to $140.13 \pm 1.46$ $\mathrm{mg} / 100 \mathrm{~g}$ in $C$. edulis. there were no significant $(\mathrm{p}>0.05)$ differences in the [phytate]:[Zn] molar ratios of the fermented seed samples. On the other hand, [Ca]:[phytate] molar ratios of the samples varied significantly $(\mathrm{p}<0.05)$ from $10.48 \pm 1.15$ of $P$. africana to $30.44 \pm 1.57$ of $C$. edulis. The calculated [Ca][phytate]:[Zn] molar ratios for the fermented seeds ranged, nonsignificantly ( $p>0.05$ ), from $0.20 \pm 0.02$ to $0.25 \pm 0.12 \mathrm{~mol} / \mathrm{kg}$ (except for $C$. edulis at $0.60 \pm 0.05 \mathrm{~mol} / \mathrm{kg}$ ).

Table 3: Concentrations of phytate, $\mathrm{Zn}, \mathrm{Ca}$ and calculated [phytate]/[Zn], [Ca]/[phytate] and [Ca][phytate]/[Zn] molar ratios of the fermented seeds analyzed.

\begin{tabular}{lcccccc}
\hline $\begin{array}{c}\text { Sample } \\
\text { (dry weight) }\end{array}$ & $\begin{array}{c}\text { Phytate } \\
(\mathbf{m g} / \mathbf{1 0 0 g})\end{array}$ & $\begin{array}{c}\text { Zn } \\
(\mathbf{m g} / \mathbf{1 0 0 g})\end{array}$ & $\begin{array}{c}\text { Ca } \\
(\mathbf{m g} / \mathbf{1 0 0 g})\end{array}$ & $\begin{array}{c}\text { [Phytate] } \\
{[\mathrm{Zn}]}\end{array}$ & $\begin{array}{c}\text { [Ca] } \\
{[\text { Phytate] }}\end{array}$ & $\begin{array}{c}\text { [Ca][Phytate] } \\
{[\mathbf{Z n}]} \\
(\mathbf{m o l} / \mathbf{k g})\end{array}$ \\
\hline Citrullus colocynthis & $50.97 \pm 10.11^{\mathrm{a}}$ & $3.72 \pm 1.51^{\mathrm{a}}$ & $71.32 \pm 13.89^{\mathrm{a}}$ & $1.52 \pm 0.99^{\mathrm{a}}$ & $25.34 \pm 1.79^{\mathrm{ab}}$ & $0.25 \pm 0.12^{\mathrm{a}}$ \\
Cucumeropsis edulis & $80.32 \pm 11.02^{\mathrm{a}}$ & $4.40 \pm 0.35^{\mathrm{a}}$ & $140.13 \pm 1.46^{\mathrm{b}}$ & $1.71 \pm 0.03^{\mathrm{a}}$ & $30.44 \pm 1.57^{\mathrm{b}}$ & $0.60 \pm 0.05^{\mathrm{b}}$ \\
Ricinus communis & $80.12 \pm 12.00^{\mathrm{a}}$ & $7.75 \pm 0.57^{\mathrm{a}}$ & $84.83 \pm 13.19^{\mathrm{a}}$ & $0.99 \pm 0.37^{\mathrm{a}}$ & $18.84 \pm 2.90^{\mathrm{a}}$ & $0.20 \pm 0.02^{\mathrm{a}}$ \\
Prosopis africana & $100.03 \pm 10.06^{\mathrm{a}}$ & $7.37 \pm 1.15^{\mathrm{a}}$ & $60.61 \pm 3.61^{\mathrm{a}}$ & $1.31 \pm 0.27^{\mathrm{a}}$ & $10.48 \pm 1.15^{\mathrm{c}}$ & $0.21 \pm 0.03^{\mathrm{a}}$ \\
\hline
\end{tabular}

Values (mean \pm standard deviation) with different superscripts per column are statistically significant $(p<0.05)$.

Figures 1- 4 show the effects of boiling alone and boiling plus $72 \mathrm{~h}$ fermentation on the seeds' contents of phytate, $\mathrm{Zn}$ and $\mathrm{Ca}$ as well as the calculated [phytate]:[Zn], [Ca]:[phytate] and [Ca][phytate]:[Zn] molar ratios. Generally, a combination of boiling and fermentation significantly $(\mathrm{p}<0.05)$ reduced phytate but increased $\mathrm{Zn}$ and $\mathrm{Ca}$ contents of the seed samples. In the same vein, boiling and fermentation significantly $(p<0.05)$ decreased [phytate]:[Zn] and [Ca][phytate]:[Zn] molar ratios, but increased [Ca]:[phytate] molar ratios of the seed samples.

\subsection{DISCUSSION}

Some lesser-known, unconventional seeds, especially legumes, and their products have been reported as possible good sources of nutrients and may have the potential of broadening the present narrow food base for humans [17, 18]. Many staple seeds, as well as some unconventional ones, have been found to contain anti-nutritional factors such as phytates. Phytates in diet chelates $\mathrm{Zn}$ leading to $\mathrm{Zn}$ deficiency, a cause of dwarfism and hypogonadism among adolescents from low social classes [8].

Results of this study showed that phytate contents of the studied seeds were in very low concentrations when compared with earlier reports on leguminous seeds [5]; beans $(205.9 \pm 112.0 \mathrm{mg} / 100 \mathrm{~g}$ ), oil seeds (164 $\pm 76.8 \mathrm{mg} / 100 \mathrm{~g})$ and locust bean $(209 \pm 191 \mathrm{mg} / 100 \mathrm{~g})$. Processing techniques involving a combination of boiling and fermentation reduced significantly $(p<0.05)$ the phytate content of all the seeds. This corroborates an earlier observation that a $20-34 \%$ reduction in the phytate levels occurred in fermented seed samples [19]. Apart from boiling and fermentation, processes such as soaking, dehydration and cooking reduce phytate levels [20]. These agree with the assertion that microflora enzymes such as phytase hydrolyze endogenous phytate fermentation leading to non-significant levels of phytate in fermented foods especially legumes but not in fermented maize and guinea corn [5].

High phytate content can decrease $\mathrm{Zn}$ and $\mathrm{Ca}$ absorption from food. The $\mathrm{Zn}$ and $\mathrm{Ca}$ contents of the studied raw seeds were appreciably high when compared with $1.3 \pm 0.5 \mathrm{mg} / 100 \mathrm{~g}$ and $37.6 \pm 6.5 \mathrm{mg} / 100 \mathrm{~g}$ respectively reported for leguminous beans samples [5]. Generally, boiling as a method of processing these seeds, non-significantly ( $p>0.05$ ) reduced $\mathrm{Zn}$ and $\mathrm{Ca}$ contents of the seeds. Ojiako et al [17] had also reported slight reductions in $\mathrm{Zn}$ and Ca contents of cooked seeds of African yam bean, African oil bean, Citrullus colocynthis and Mucuna flagellipes. On the other hand, combination of boiling and fermentation non-significantly $(\mathrm{p}<0.05)$ increased $\mathrm{Zn}$ (except for $P$. africana), but significantly $(\mathrm{p}<0.05)$ increased Ca (except for $R$. communis) contents of all the sampled seeds. These observations may explain the 

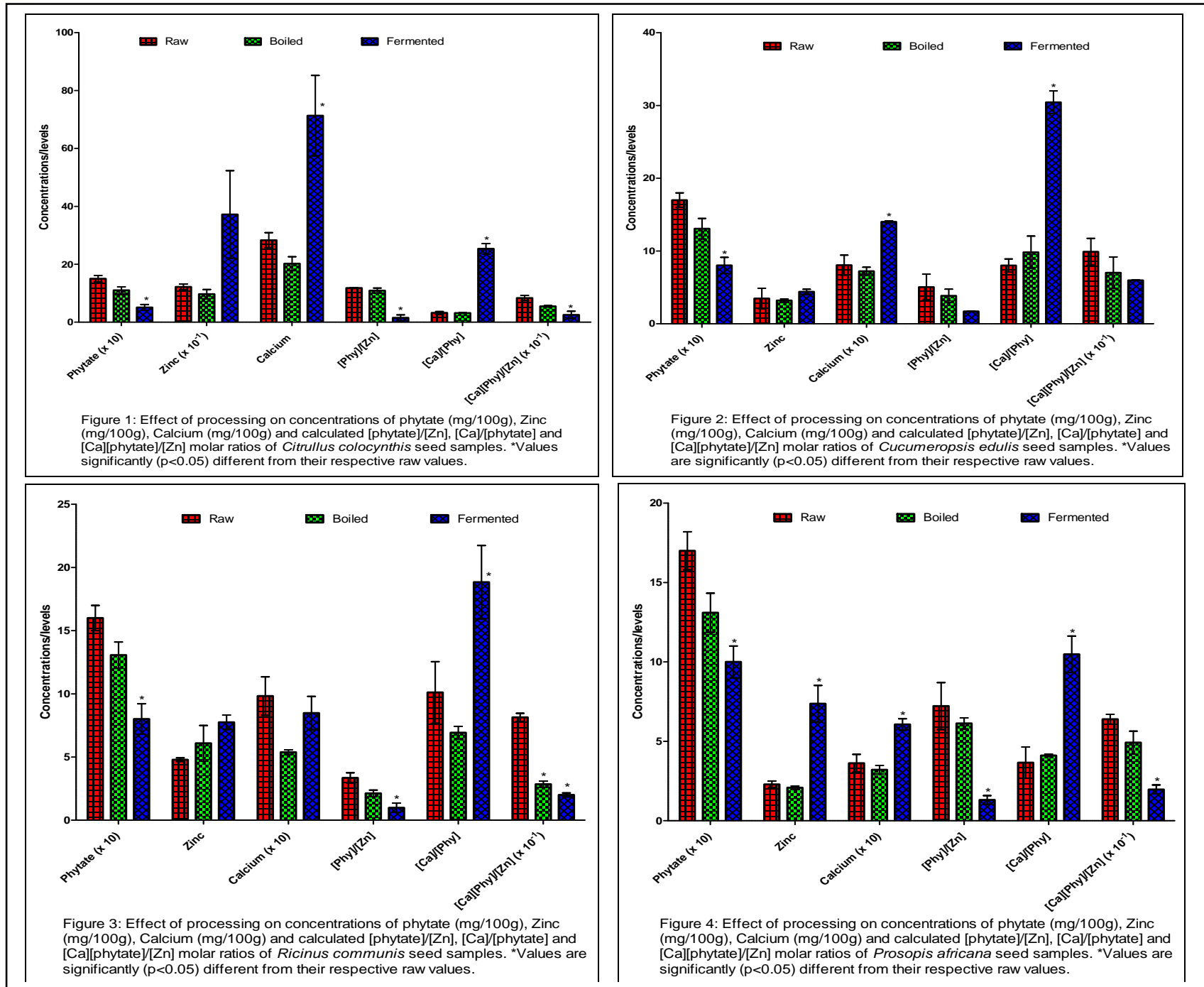

report that fermentation improves flavor and taste, and has been widely described as an economic processing method used in homes to improve nutritional qualities of foods, while minimizing their anti-nutritional contents [18].

Phytate to $\mathrm{Zn}$ molar ratio has been variously reported as an index of $\mathrm{Zn}$ bioavailability ${ }^{7}$. The [phytate]/[Zn] molar ratio of the studied raw seeds were between 5-15 (except $R$. communis at $3.35 \pm 0.40$ ), a range described by WHO [13] as being equivalent to moderate $\mathrm{Zn}$ bioavailability. Interestingly, the combined processes of boiling and $72 \mathrm{~h}$ fermentation significantly $(p<0.05)$ reduced the [phytate]/[Zn] molar ratios of all the seeds to be $<5$, which is equivalent to high $\mathrm{Zn}$ bioavailability [13]. The [Ca]/[phytate] molar ratio of the raw seeds of $C$. edulis and $R$. communis were above, while those of $C$. colocynthis and $P$. africana were below 6 , the positive predictive critical value [17]. The processing technique of boiling and fermentation significantly $(p<0.05)$ increased the [Ca]/[phytate] molar ratios of all the seeds to above 6 . As has been earlier reported, Ca has a sparing effect on $\mathrm{Zn}$, and at critical [Ca]/[phytate] molar ratio of $\geq 6: 1$, phytate is completely precipitated from the solution. Thus, $\mathrm{Zn}$ is available in solution and for absorption [17]. This means that both the solubility of phytate and the availability of $\mathrm{Zn}$ in the intestine is dependent on dietary Ca levels. This has led to the idea that [Ca][phytate]/[Zn] molar ratio, with a critical value of $0.50 \mathrm{~mol} / \mathrm{kg}$ may be a better index for predicting Zn bioavailability than either of [phytate]/[Zn] or [Ca]/[phytate]. Calculated [Ca][phytate]/[Zn] molar ratios obtained in this study, showed that the raw seeds had ratios higher than the proposed critical value of $0.50 \mathrm{~mol} / \mathrm{kg}$. However, these seeds are never consumed raw but either cooked, boiled and/or fermented. Boiling and fermentation significantly $(p<0.05)$ reduced the [Ca][phytate]/[Zn] molar ratios of the seeds to values less than $0.50 \mathrm{~mol} / \mathrm{kg}$ (except for $C$. edulis at $0.60 \pm 0.05 \mathrm{~mol} / \mathrm{kg}$ ). These results are in consonance with $0.17 \pm 0.13 \mathrm{~mol} / \mathrm{kg}$ and $0.21 \pm 0.12 \mathrm{~mol} / \mathrm{kg}$ earlier observed for beans and locust bean [5].

In conclusion, the results of the study showed that these seeds are good nutrient sources with high Zn bioavailability, which can be significantly improved by a combined process of boiling and fermentation. The observations further highlighted the beneficial effects of a combination of both techniques on nutritional and anti-nutritional contents of food materials. The study also elucidated the high $\mathrm{Zn}$ bioavailability of condiments commonly produced from these lesserknown seeds. Taking the above points into consideration, and the easy availability of these seeds, as well as the relatively little cost of sourcing them, we wish to recommend their integration fully into human nutrition, especially in areas prone to Zn deficiency. 


\section{REFERENCES}

[1] Achi, O.K. 2005. The upgrading of traditional fermented foods through Biotechnology. Afr J Biotech 4: 373-380.

[2] Eka, O.U. 1980 Effect of fermentation on the nutrient status of Locust beans. Food Chem 5: 305-308.

[3] Ogbonna, D.N., Sokari, T.G. and Achinewhu, S.C. 2001. Development of an owoh-type product from African yam beans (Sphenostylis stenocarpa) by solid substrate fermentation. Plant Foods Human Nutr 56: 183-194.

[4] Achinewhu, S.C. 1986. Some biochemical and nutritional changes during the fermentation of fluted pumpkin (Telferia occidentale). Plant Foods Human Nutr 36: 97.

[5] Adeyeye, E.I., Arogundade, L.A., Akintayo, E.T., Aisida, O.A. and Alao, P.A. 2000. Calcium, zinc and phytate interrelationships in some foods of major consumption in Nigeria. Food Chem 71: 435-441.

[6] Harland, B.F. and Oberleas, D. 1987. Phytate in Foods. In: Bourbe, G.H. World Review of Nutrition and Dietetics. Karger, Basel, Switzerland.

[7] Gargari, B.P., Mahboob, S. and Razavieh, S.V. 2007. Content of phytic acid and its mole ratio to zinc in flour and breads consumed in Tabriz, Iran. Food Chem 100: 1115-1119.

[8] Prasad AS: Zinc deficiency. British Med J 326(7386): 409-410.

[9] Oberleas, D. 1983. Phytate content in cereals and legumes and methods of determination. Cereal Foods World 352357.

[10] Davis, N.T. and Olpin, S. 1979. Studies on the phytate:zinc molar content in diet as a determinant of Zn availability to young rats. British $\mathrm{J}$ Nutr 41: 591-603.

[11] Morris, E.R. and Ellis, R. 1989. Usefulness of the dietary phytic acid/zinc molar ratio as an index of zinc bioavailability to rats and humans. Biol Trace Element Res 19(1-2): 107-117.

[12] Ellis, R., Kelsay, J.L., Reynolds, R.D., Morris, E.R., Moser, P.B. and Frazier, C.W. 1987. Phytate:zinc and phytate $x$ calcium: zinc millimolar ratios in self-selected diets of Americans, Asian Indians and Nepalese. J Amer Dietary Asso. 87: 1043-1047.

[13] World Health Organization (WHO). 1996. Trace Element in Human Nutrition and Health, Geneva.

[14] Onwuka, G.I. 2005. Food Analysis and Instrumentation. Naphthali Prints, Lagos.

[15] International Zinc Nutrition Consultative Group (IZiNCG). 2004. Assessment of the risk of zinc deficiency in populations and options for its control. In: Hotz, C. and Brown, K.H. (eds): Food and Nutrition Bulletin, Vol. 25, No. 1, (Suppl. 2): S113-S118.

[16] Wyatt, C.J. and Triana-Tejas, A. 1994. Soluble and insoluble Fe, Zn, Ca, and phytates in foods commonly consumed in Northern Mexinco. J Agric Food Chem. 42: 2204-2209.

[17] Ojiako, A.O., Ogbuji, C.A., Agha, N.C. and Onwuliri, V.A. 2010. The proximate, mineral and toxicant compositions of four possible food security crops from Southeastern Nigeria. J Med Food 13(5): 1203-1209.

[18] Onwuliri, V.A., Atta, I. and Nwankwo, J.O. 2004. Antinutritional factors, essential and non-essential fatty acids composition of ugba (Pentaclethra macrophylla) seeds at different stages of processing and fermentation. J Biol Scs 4(5): 671-675.

[19] Ene-Obong, H.N. 1995. Content of antinutrients and cowpea. Plant Food and Human Nutr 45: 165-170.

[20] Ihekoronye, A.I. and Ngoddy, P.O. 1985. Integrated Food Science and Technology for the Tropics. BasingstokeMacmillan Publishers, London.
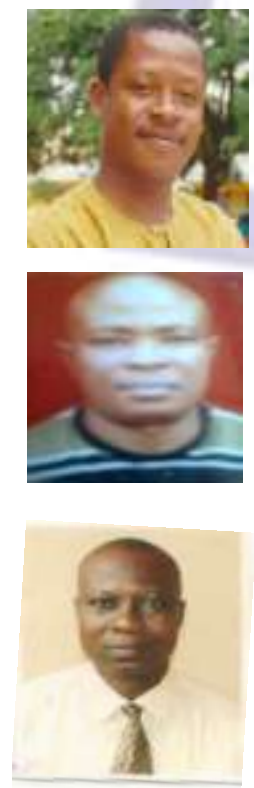

Chidi Uzoma Igwe. Doctor of Medical Biochemistry, a Biomedical Scientist and 41 years old. He lectures at Department of Biochemistry, Federal University of Technology, Owerri, Nigeria and has more than 50 scientific publications to his credit. He is interested in the use of African pharmacopeia and lesser-known edible plants for the control, management and treatment of physiological diseases and malnutrition in vulnerable communities of Africa.

Dr. C.O. Ibegbulem holds a Ph. D in Biochemistry. . He is a senior lecturer in the Department of Biochemistry, Federal University of Technology Owerri, Imo State, Nigeria. His research interests try unravelling some of the secrets of nature using very simple techniques.

Dr. Linus A. Nwaogu holds a Ph.D. in Environmental Biochemistry. He is a senior lecturer in the Department of Biochemistry, Federal University of Technology Owerri, Imo State, Nigeria. He is 43 years of age and married with children. His main area of specialization and research is Environmental Biochemistry. 

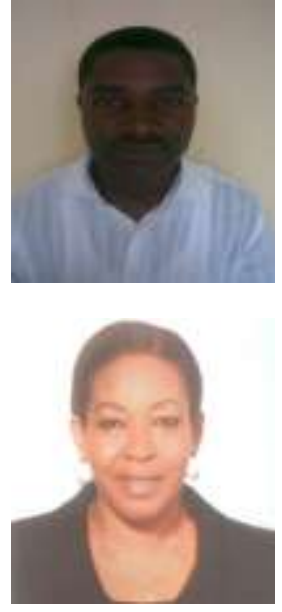

Dr. Cosmas O. Ujowundu holds a Ph. D in Environmental Biochemistry. He teaches different aspects of Biochemistry at the Department of Biochemistry, Federal University of Technology, Owerri, Nigeria. His works are in Environmental Toxicology and Nutritional Toxicology. He is interested in the use of nature to remedy environmental challenges induced by anthropogenic activities of man. He exploits the biochemical similarities and differences conferred by the genetic makeup of organisms to achieve this.

Gloria Nkiruka Okwu holds a Doctorate degree in Nutritional/Medical Biochemistry. A Senior Lecturer in the Department of Biochemistry and Ag. Director, Office For University Development, Federal University of Technology, Owerri. She has over 30 scientific publications to her credit. Her research interests are in the areas of Nutrition, Toxicology, Maternal and Child health. 